\title{
Polarisasi Cahaya dan Penentuan Nilai Indeks Bias dengan Metode Sudut Brewster
}

\author{
Istiqomah Nugraheny, ${ }^{1, *}$ Wahyu Nurfauzi, ${ }^{1}$ Devara Ega Fausta, ${ }^{2}$ Supurwoko, ${ }^{1}$ dan Rengga Ngesthi Pambuka ${ }^{1}$ \\ ${ }^{1}$ Program Studi Pendidikan Fisika, Fakultas Keguruan dan Ilmu Pendidikan, \\ Universitas Sebelas Maret, Jln. Ir Sutami 36A Kentingan Surakarta 57126 \\ ${ }^{2}$ Prodi Fisika, Fakultas Matematika dan Ilmu Pengetahuan Alam, \\ Universitas Sebelas Maret, Jln. Ir Sutami 36A Kentingan Surakarta 57126
}

\begin{abstract}
Intisari
Sebuah eksperimen untuk menentukan sudut Brewster dan mempelajari polarisasi dari pantulan cahaya telah dilakukan. Peralatan yang digunakan berupa sebuah meja spektrofotometer sebagai tempat meletakkan sampel dan membaca sudut sinar pantul, fotodetektor sebagai pencatat nilai intensitas cahaya pantul, resin sebagai sampel uji, laser He-Ne sebagai sumber cahaya utama, dan polarizer digunakan untuk mempolarisasi cahaya. Hasil yang diperoleh bahwa terdapat dua jenis polarisasi cahaya yang dapat dipelajari yakni berupa mode TE dan TM. Mode yang digunakan untuk menentukan sudut Brewster berupa Mode TM. Nilai sudut Brewster yang diperoleh sebesar 52,5 untuk sampel resin. Nilai Indeks bias yang diperoleh sebesar(1,303 $\pm 0,055)$. Sementara nilai dari literatur yang diperoleh sebesar $(1,46 \pm 0,01)$.
\end{abstract}

\begin{abstract}
An experiment for determining Brewster angle and study polarization from reflected light has been done. Equipment for this experiment are a spectrophotometry table as the place the sample and read the reflected angle, photodetector as recording instrument to determine value of intensity from reflected light, resin as tested sample, He-Ne Laser as main light resource, and a polarizer used as light polarizator. The result from this experiment shown there are 2 mode from polarized light, TE mode and TM mode. Mode which is used to determine the Brewster angle is TM Mode. The value of brewster angle from resin sample on this experiment is $52,5^{\circ}$. The value from refractive index is $(1.303 \pm 0.055)$ compared by the literature which has been used is $(1.46 \pm 0.01)$.
\end{abstract}

KATA KUNCI: Brewster angle, polarization, resin sample, refractive index http://dx.doi.org/10.12962/j24604682.v14i3.3867

\section{PENDAHULUAN}

Cahaya merupakan salah satu bidang kajian yang telah lama diteliti oleh para ilmuwan fisika. Cahaya mempunyai banyak fenomena yang dapat diteliti dan dikaji oleh para ilmuwan dari masa ke masa. Salah satu fenomena yang masih diselidiki sampai saat ini adalah fenomena polarisasi cahaya. Polarisasi cahaya pertama kali ditemukan oleh fisikawan asal Prancis E. Mallus yang melakukan eksperimen dengan menggunakan bahan dielektrik. Hasil penemuannya ini kemudian membuat para ilmuwan pada jaman itu tertarik mempelajari tentang polarisasi cahaya [1].

Salah satu ilmuwan yang berhasil menemukan fenomena pada polarisasi cahaya adalah Brewster. Untuk pertama kali Brewster berhasil menunjukkan bahwa pantulan cahaya tidak selamanya terpolarisasi secara sempurna dan pelebaran cahaya terpolarisasi bergantung pada sudut datangnya. Cahaya menjadi terpolarisasi sempurna pada sudut spesifik dari arah datang yang ditentukan oleh cahaya pantul yang ditentukan oleh indeks bias kedua sisi dari batas refleksi. Sudut yang be-

*E-MAIL: istiqomahlah97@gmail.com rada pada kondisi tersebut saat ini dikenal sebagai sudut Brewster. Eksperimen Brewster mengarahkan pada penemuan dari beberapa teori dasar tentang polarisasi pada cahaya pantul. Dari eksperimen yang dilakukan oleh Brewster, didapatkan persamaan [1]:

$$
\tan \theta=\frac{n_{1}}{n_{2}}
$$

Hingga saat ini, studi tentang polarisasi cahaya merupakan salah satu bahasan yang cukup menarik dikalangan ilmuwan. Polarisasi cahaya dipelajari dalam berbagai bidang keilmuwan, diantaranya: bidang material sains, biologi, astronomi, dan analisis forensik. Polarisasi cahaya oleh pemantulan pada sudut Brewster mempunyai beragam aplikasi, seperti: menurunkan pemantulan material, menentukan nilai indeks bias yang tinggi dari permata, serta merupakan dasar dari teknik mikroskopi yang dinamakan sebagai mikroskop sudut Brewster [2]. Penggunaan sudut Brewster sebagai metode dalam menentukan indeks bias suatu bahan memiliki kelebihan diantaranya tingkat ketelitian yang tinggi, metode ini sangat sesuai dengan berbagai jenis lapisan transparan, metode yang murah dalam segi biaya, dan mudah dalam melakukan analisisnya [3].

Dalam dunia perguruan tinggi, khususnya jurusan sains pengenalan materi optik telah dilaksanakan sejak mahasiswa 
duduk pada semester tingkat pertama. Banyak buku teks yang telah menjelaskan berbagai materi bidang optik [4, 5] untuk mahasiswa tingkat pertama. Penyampaian beberapa materi dalam kelas biasanya diikuti adanya eksperimen laboratorium. Akan tetapi, kebanyakan eksperimen yang berkaitan tentang optik masih terbatas, terutama dalam sub topik polarisasi dan metode Brewster. Publikasi ilmiah yang berkaitan dengan topik polarisasi dan metode Brewster dapat untuk tujuan pembelajaran masih kurang. Hanya beberapa artikel yang mempublikasikan dengan tujuan tersebut $[1,6]$. Kebanyakan publikasi yang telah diterbitkan sudah dalam bentuk aplikasi suatu bidang dengan langkah kerja yang sulit untuk dipahami, terutama bagi mahasiswa tingkat pertama. $\mathrm{Pu}-$ blikasi kali ini bertujuan untuk memberikan pengenalan tentang polarisasi cahaya dan metode Brewster. Hal ini dilakukan dengan menentukan indeks bias suatu bahan dengan mencari nilai sudut Brewster dari bahan tersebut. Lewat publikasi ini diharapkan pembelajaran tentang polarisasi dan sudut Brewster lebih dapat dikenal serta diaplikasikan menjadi salah satu topik eksperimen bagi mahasiswa tingkat awal.

\section{METODOLOGI EKSPERIMEN}

Eksperimen penentuan sudut Brewster menggunakan sampel berupa resin bening. Resin difabrikasi dengan menggunakan bantuan katalis untuk mempercepat proses pengenceran dan pengeringannya. Komposisi resin dan katalis yang digunakan menggunakan komposisi $60 \mathrm{ml}$ resin dan $4 \mathrm{ml}$ katalis. Dari hasil fabrikasi diperoleh resin berwarna putih pekat dengan ketebalan sampel sebesar $2,5 \mathrm{~cm}$. Penggunaan resin dalam eksperimen ini dikarenakan resin merupakan salah satu jenis bahan dielektrik selain kaca. Dalam bidang optik, resin diaplikasikan sebagai media cladding untuk fiber optik [13]. Sehingga resin dapat dijadikan sebagai salah satu objek yang dapat diambil nilai indeks biasnya. Apabila dicari lebih lanjut, dengan mengetahui nilai indeks bias dari core dan cladding suatu bahan penyusun fiber optik, maka dapat ditentukan nilai NA fiber optik tersebut.

Dalam eksperimen ini, intensitas dari sampel akan dihitung dengan bantuan skala pada spektrometer dan nilai indeks bias akan diperoleh dengan menggunakan metode Brewster. Untuk mencari nilai indeks bias dengan metode Brewster diperlukan beberapa komponen alat seperti fotodetektor dan seperangkat PC, sampel resin, skala spektrometer (goniometer), polarizer dan sumber cahaya. Skema eksperimen ditunjukkan pada Gambar 1.

Sumber cahaya yang digunakan pada eksperimen ini berupa laser Helium-Neon (He-Ne) dengan panjang gelombang yang telah diukur sebesar $(642,5293 \pm 0,3112) \mathrm{nm}$ [7]. Polarizer digunakan untuk mempolarisasi cahaya dalam mode TE Transfer Electric dan TM Transfer Magnetic. Sementara sampel diletakkan di atas goniometer dan diatur supaya paralel dengan sudut $90^{\circ}$.

Penggunaan istilah mode TE dan TM dalam eksperimen iniadalah untuk menggambarkan tentang peristiwa polarisasi cahaya. Sebagai salah satu bentuk gelombang elektromagnetik, cahaya tentunya mempunyai 2 buah komponen, yakni

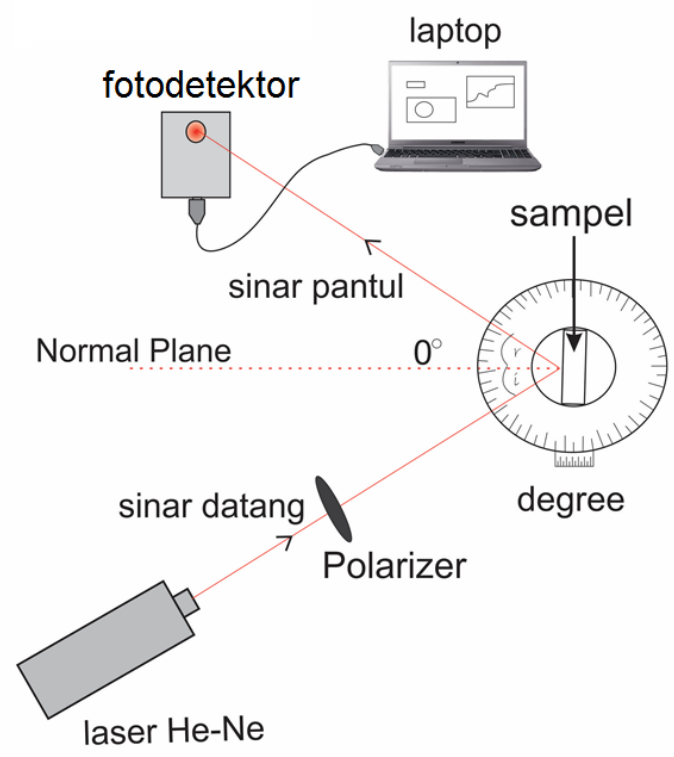

Gambar 1: Skema alat brewster.

komponen medan listrik dan medan magnet. Dimana medan listrik bergerak tegak lurus terhadap bidang rambat sementara medan magnet bergerak paralel atau sejajar dengan medan rambatnya [9]. Untuk menentukan mode TE dan TM dari eksperimenini digunakan polarizer dengan orientasi sudut yang berbeda, yakni pada nilai $0^{\circ}$ dan $90^{\circ}[6,10,11]$. Pada mode TE, digunakan posisi sudut polarizer sebesar $0^{\circ}$, sehingga komponen yang tegak lurus dapat merambat melewati polarizer. Sementara pada mode TM, digunakan sudut polarizer sebesar $90^{\circ}$, sehingga komponen yang mempunyai arah perambatan sejajar dapat bergerak melewati polarizer. Karena di dalam cahaya cenderung mempunyai komponen medan listrik dibandingkan medan magnet [6], maka nilai intensitas yang diperoleh pada mode TE akan lebih besar dibandingkan pada mode TM. Karena pada mode TE, medan lisrtik yang diloloskan oleh polarizer lebih banyak dibandingkan dengan mode TM. Hal tersebut dapat dilihat pada Gambar 2.

Sementara itu, penggunaan spektrometer pada eksperimen ini dikarenakan skala spektrometer memiliki presisi yang baik. Selain itu skala nonius terkecil yang dimiliki mempunyai nilai hingga $10 / 60^{\circ}$. Hal ini sangat sesuai dengan metode Brewster yang memerlukan tingkat sensitivitas dan ketelitian yang tinggi [8]. Cahaya laser yang dipantulkan oleh sampel akan ditangkap oleh seperangkat fotodetektor berbasis Arduino-Uno yang telah dirancang menggunakan PC.

Tahapan pertama adalah memastikan cahaya pantul pada sudut $0^{\circ}$ dari cahaya datang hanya ada satu titik. Sampel harus ditempatkan dengan benar untuk memperoleh titik yang tepat dari pantulan cahaya. Selama proses pengambilan data ruangan yang digunakan haruslah gelap. Prinsip dari pengambilan data yang dilakukan adalah dengan meningkatkan nilai sudut datang dan mengamati cahaya yang terpantulkan oleh sampel.

Pada penelitian ini digunakan 3 fase pengambilan data untuk memperoleh nilai dari sudut Brewster. Fase pertama, yaitu 
dengan menggunakan polarizer pada sudut $0^{\circ}$ sebagai mode TE dan $90^{\circ}$ sebagai mode TM. Variasi skala goniometer yang digunakan sebesar $10^{\circ}$, sehingga diperoleh intensitas pada sudut $10,20,30,40,50,60,70,80$, dan $90^{\circ}$. Intensitas kemudian dibandingkan dengan cahaya yang tidak terpolarisasi. Dari fase pertama ini dapat diperoleh nilai reflektansi terkecil dari bahan pada sudut tertentu. Nilai ini dijadikan acuan untuk pengambilan data pada fase selanjutnya.

Fase kedua ditentukan berdasarkan hasil dari nilai yang dekat dengan nilai reflektansi terendah pada fase pertama. Setelah itu dilakukan prosedur yang sama dengan menggunakan rentang skala sudut sebesar $1^{\circ}$. Pafa fase terakhir, digunakan skala sebesar $1 / 6^{\circ}$ menggunakan bantuan skala nonius goniometer hingga memperoleh nilai reflektansi terkecilnya. Sudut dengan letak reflektansi terkecil dari fase terakhir ini dinamakan sebagai sudut Brewster.

\section{HASIL DAN DISKUSI/PEMBAHASAN}

Eksperimen penentuan sudut Brewster pada resin bening telah berhasil dilakukan. Pada eksperimen ini, telah diambil 3 jenis data hubungan intensitas dengan variasi sudut datang sinar yang berbeda-beda. Untuk mendapatkan reflektansi dari laser digunakan persamaan:

$$
R=\frac{I_{y}}{I}
$$

dengan $\mathrm{R}$ merupakan reflektansi cahaya, sedangkan $\mathrm{I}_{y}$ merupakan nilai intensitas cahaya pada posisi tertentu dan I merupakan nilai intensitas awal dari laser He-Ne. Sehingga, pada eksperimen ini nilai dari reflektansi cahaya dapat ditentukan.

Pada eksperimen ini terdapat 3 fase pengambilan data, fase pertama digunakan variasi sudut pada goniometer sebesar $10^{\circ}$ hingga $90^{\circ}$ dengan interval sudut sebesar $10^{\circ}$. Pada fase ini pula dapat dijelaskan perbedaan polarisasi jenis TE dan TM. Polarisasi TE merupakan cahaya yang mengalami polarisasi secara tegak lurus. Sementara polarisasi TM merupakan cahaya yang mengalami polarisasi secara paralel [9]. Keakuratan untuk memperoleh sudut Brewster ditentukan dari reflektansi minimum pada mode TM [10]. Mode TM cenderung memiliki nilai reflektansi yang lebih rendah dibandingkan dengan mode TE [11]. Gambar 2 merupakan hasil perbandingan antara mode TE dan TM.

Gambar 2 memperlihatkan perbandingan mode antara TE dan TM pada nilai sudut datang yang sama. Besar reflektansi pada mode TE dan TM mempunyai nilai yang hampir sama. Sebagaimana nilai sudut datang semakin meningkat maka intensitas dari mode TE mengalami peningkatan sementara pada mode TM relatif stabil dan mengalami penurunan [1]. Pada fase pertama, reflektansi terkecil yang berhasil terukur pada mode TM yang berada pada posisi sudut $50^{\circ}$. Sudut ini digunakan sebagai acuan untuk melakukan pengukuran fase kedua.

Hasil pengukuran pada fase kedua ditunjukkan pada Gambar 3. Pada fase ini, digunakan rentang pengambilan data dari goniometer sebesar $46^{\circ}$ hingga $55^{\circ}$ dengan variasi sudut $1^{\circ}$. Nilai reflektansi terkecil yang diperoleh berada pada sudut

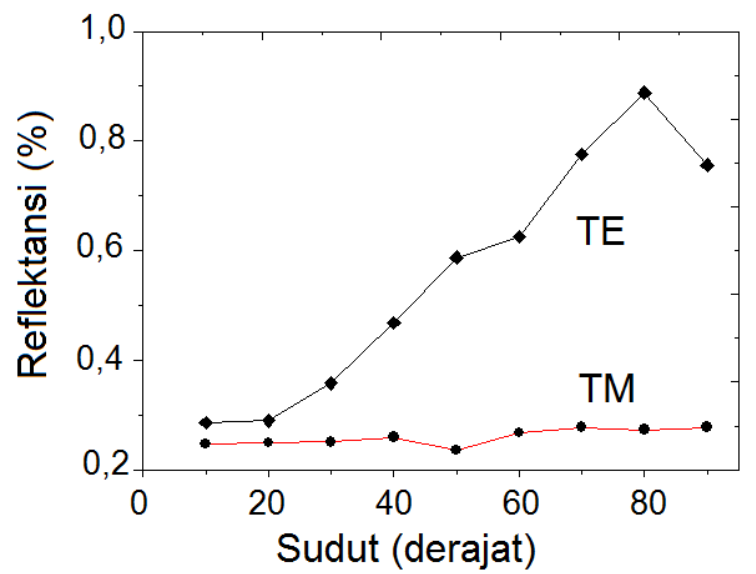

Gambar 2: Perbandingan Mode TE dan TM pada skala $10^{\circ}$.

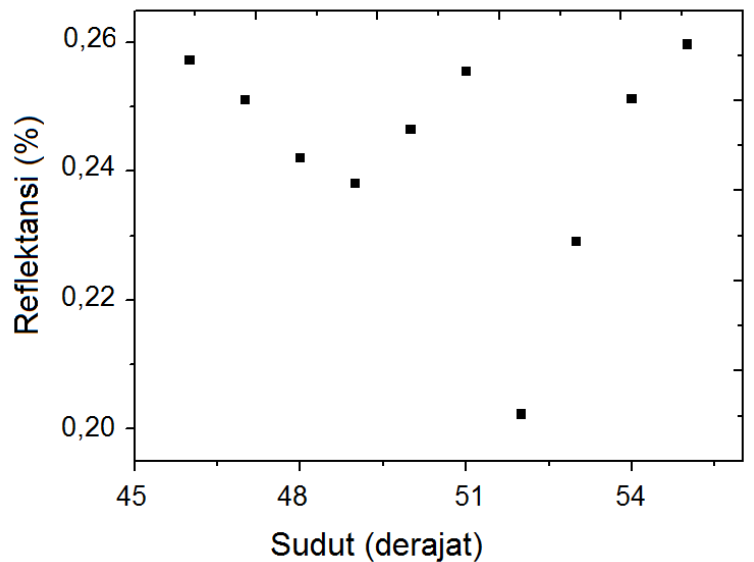

Gambar 3: Hubungan reflektansi dengan sudut pada skala $1^{\circ}$

$52^{\circ}$. Hasil pengukuran pada fase ketiga ditunjukkan pada Gambar 4. Pengukuran pada fase ketiga dilakukan dengan rentang sudut dari goniometer sebesar $51,67^{\circ}$ hingga $52,83^{\circ}$ dengan variasi sudut sebesar $1 / 6^{\circ}$. Dari fase ketiga diperoleh nilai reflektansi terkecil pada sudut $52,5^{\circ}$. Sudut pada fase ketiga ini dinamakan sebagai sudut Brewster.

Pada fase ke-1 hingga fase ke-3 selalu dicari nilai reflektansi terkecil untuk menentukan nilai sudut Brewster. Hal tersebut dikarenakan sudut Brewster merupakan sudut yang terbentuk pada saat nilai reflektansi suatu sinar datang hampir mendekati nol. Atau dengan kata lain hampir tidak ada berkas cahaya yang dapat dipantulkan kembali [8]. Karena pada saat eksperimen, berkas pantulan cahaya yang coba ditangkap oleh detektor sudah hampir tidak terlihat lagi dan nilai intensitas yang terbaca berkisar diantara 0,2-0,19 seperti yang terlihat pada Gambar 3 dan 4.

Kemudian dengan menggunakan Pers.(1), diperoleh nilai indeks bias dari material resin adalah sebesar 1,303. Ketidakpastian pada pengukuran ini diperoleh dari $1 / 3$ skala terkecil dari alat [12] yakni sebesar 0,055. Sehingga Indeks bias dari resin bening yang diperoleh adalah $(1,303 \pm 0,055)$. Nilai 


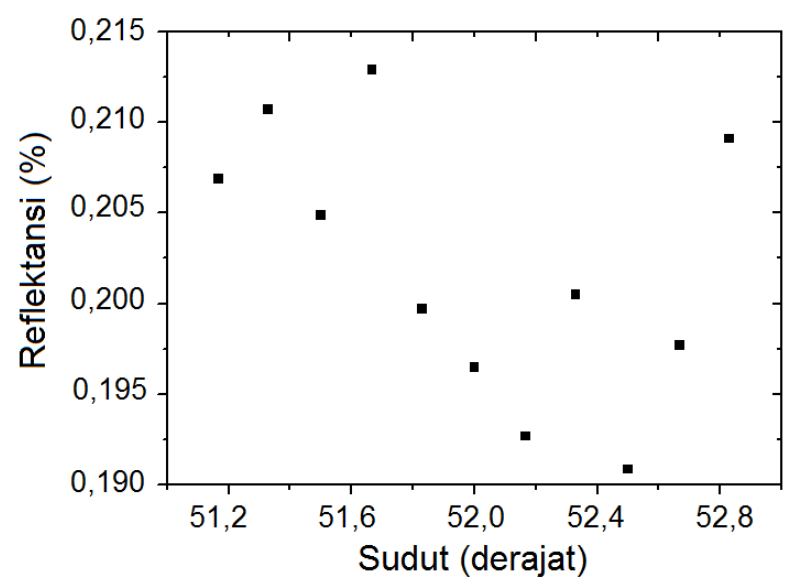

Gambar 4: Hubungan Reflektansi dengan sudut pada skala 1/6.

indeks bias yang diperoleh pada eksperimen ini mendekati nilai referensi resin bening yakni sebesar $(1,46 \pm 0,01)$ [13]. Ketelitian yang dihasilkan mencapai $89 \%$.

Perbedaan nilai indeks bias yang diperoleh dalam eksperimen ini dapat disebabkan oleh banyak hal. Beberapa faktor yang dapat mengakibatkan nilai indeks bias pengukuran berbeda dengan nilai referensi yang digunakan adalah: pertama, material resin yang digunakan masih terdapat rongga udara di dalamnya yang dapat dilihat dengan adanya kumpulan gelembung kecil walaupun tidak banyak hal ini dapat menyebabkan cahaya terhambur dan intensitas cahaya yang diterima oleh detektor tidak maksimal. Kedua adanya cahaya luar yang masuk pada saat proses pengambilan data sehingga mempengaruhi kemampuan kerja detektor. Terakhir, laser He-Ne yang digunakan sebagai sumber cahaya mudah panas, ketika laser He-Ne dalam keadaan panas maka nilai in- tensitas yang dihasilkan akan menurun. Perubahan nilai ini dapat menurunkan tingkat keakuratan data yang diperoleh. Oleh karenanya untuk eksperimen ke depannya perlu diperbaiki kembali kekurangan tersebut.

Terlepas dari hasil yang diperoleh, eksperimen dengan metode Brewster menawarkan suatu media pembelajaran untuk menentukan nilai indeks bias bahan dengan cukup sederhana, mudah dipahami, serta tingkat akurasi data yang cukup baik apabila semua komponen eksperimen dalam keadaan baik. Selain itu metode Brewster menawarkan cara yang mudah dan cepat dalam melakukan analisis indeks bias [14]. Selain itu, melalui metode ini mahasiswa juga dapat mempelajari bahwa cahaya dapat terpolarisasi secara tegak lurus dan paralel terhadap bidang polarizer dengan posisi sudut tertentu. Kedepannya jenis sampel yang dapat dijadikan bahan uji dapat diperbanyak supaya mahasiswa dapat mengetahui nilai indeks bias dari beberapa jenis bahan melalui metode Brewster [6]. Sehingga, metode ini dapat dijadikan sebagai salah satu topik eksperimen yang sesuai untuk membantu pemahaman mahasiswa dalam ranah gelombang dan optik.

\section{SIMPULAN}

Eksperimen menentukan nilai indeks bias pada sampel resin bening telah berhasil dilakukan dengan menggunakan metode sudut Brewster. Nilai sudut Brewster yang diperoleh dari eksperimen ini sebesar $52,5^{\circ}$. Nilai indeks bias yang terukur dari eksperimen ini adalah $(1,303 \pm 0,055)$ dengan keakuratan mencapai $89 \%$. Dengan menggunakan peralatan yang tersedia di laboratorium serta metode eksperimen yang relatif mudah dipahami, maka eksperimen ini dapat dijadikan sebagai salah satu topik dalam pembelajaran Optik bagi mahasiswa tingkat awal.
[1] P.J. Ouseph, et al., "Polarization of light by reflection and the Brewster angle ", Am. J.Phys., vol. 69, pp. 1166-1168, 2001.

[2] C. Bahrim and W. Hsu, "Precise measurements of the refractive indices for dielectrics using an improved Brewster angle method", Am. J.Phys., vol. 77, pp. 337-343, 2009.

[3] D.L. Moreno, et al., "Refractive index measurement of pure and $\mathrm{Er}^{3+}$-doped $\mathrm{ZrO}_{2} \mathrm{SiO}_{2}$ solgel film by using the Brewster angle technique", Optical Material, vol. 19, pp. 275-281, 2002.

[4] D. Halliday, Resnick, and Walker, "Fundamental of Physics", 8th edition, Willey India, 2008.

[5] R.A. Serway and J.W. Jeweet, "Physics for science and engineers", 6th edition, Cengage learning, 2004.

[6] R.B. Khaparde, et al., "Reflection of Polarized Light", Physics Education, vol. 24, pp. 0970-5953, 2007.

[7] K.M. Wibowo, "Desain kaca TZBN untuk fiber optic berNumerical Apperture (NA) rendah", Skripsi S.Si, Universitas Sebelas Maret, Surakarta, 2013.

[8] C.H.Grossman, and A.F.Garito, "Brewster angle method for refractive index measurements of biaxial organic systems", Mol. Cryst. Liq. Cryst, vol. 168, pp. 255-267, 1989.
[9] U. Hanspal, "Determination of Brewster Angle for Glass and plastic using Polarized Monochromatic Light Source", Manchester Collage, 2008.

[10] M.N.R. Jauhariyah, W. Setyarsih, A. Marzuki, Cari, "Refractive Index Measurement of Tellurite Glasses by Using Brewster Angle Method", International Seminar on Sensors, Instrumentation, Measurement and Metrology (ISSIMM), Malang, Agustus, 2016 .

[11] D.E. Fausta, "Fabrikasi dan Karakterisasi Kaca $\mathrm{TeO}_{2}-\mathrm{ZnO}$ $\mathrm{Na}_{2} \mathrm{O}$ (TZN) Doping $\mathrm{TiO}_{2}$ sebagai Self Cleaning Material", Skripsi S.Si, Universitas Sebelas Maret, Surakarta, 2017.

[12] B.D. Djonoputro, ”Teori Ketidakpastian”, Penerbit ITB Bandung, 1984.

[13] R.D.Sejati, A.P. Utomo, Riyatun, "Fabrikasi dan Karakterisasi Preform Fiber Optik Berbasis Kaca Tellurite $\left(\mathrm{TeO}_{2}\right)$ ", Pros. Pertemuan Ilmiah XXIX HFI Jateng \& DIY, Yogyakarta, April, 2015.

[14] J. Kumar, "Determination of Brewster's Angle of Transparent Material”, Brewster's Angle, vol. 12, no. 3, pp. 1-9, 2012. 